\title{
Comparison of Suspended Branch and Direct Infestation Techniques for Artificially Infesting Hemlock Seedlings with the Hemlock Woolly Adelgid for Resistance Screening
}

\section{Zaidee L. Powers ${ }^{1}$, Albert E. Mayfield III ${ }^{2}$, John Frampton ${ }^{3}$ and Robert M. Jetton ${ }^{1, *}$}

1 Camcore, Department of Forestry and Environmental Resources, North Carolina State University, 2720 Faucette Drive, Raleigh, NC 27695, USA; E-Mail: zlpowers@ncsu.edu

2 USDA Forest Service, Southern Research Station, 200 W.T. Weaver Boulevard, Asheville, NC 28804, USA; E-Mail: amayfield02@fs.fed.us

3 Christmas Tree Genetics Program, Department of Forestry and Environmental Resources, North Carolina State University, 2720 Faucette Drive, Raleigh, NC 27695, USA;

E-Mail: frampton@ncsu.edu

* Author to whom correspondence should be addressed; E-Mail: rmjetton@ncsu.edu; Tel.: +1-919-515-6425; Fax: +1-919-515-6430.

Academic Editors: Fei-Hai Yu and Eric J. Jokela

Received: 14 April 2015 / Accepted: 3 June 2015 / Published: 8 June 2015

Abstract: The hemlock woolly adelgid (Adelges tsugae Annand) is an invasive forest pest in eastern North America that has caused significant decline and mortality in populations of eastern hemlock (Tsuga canadensis (L.) Carr.) and Carolina hemlock (T. caroliniana Engelm.). The breeding of adelgid-resistant genotypes for reforestation activities is still in the early development phases, and most resistance screening programs have depended on labor-intensive direct artificial infestation techniques for introducing adelgids to target seedlings. We investigated the timing and effectiveness of a potentially less labor-intense suspended branch infestation technique compared to two levels of a direct infestation method. Results indicated that peak crawler emergence from adelgid infested hemlock branches occurred within a 10 to 14 day period and that crawler emergence was higher from non-hydrated compared to hydrated branches. Greater infestation pressure was achieved when using progrediens crawlers compared to sistens crawlers. In 2013, when the infestation attempts were most successful, the suspended branch technique induced the same or higher adelgid densities on target seedlings as the direct infestation techniques. Assuming an initial investment in infrastructure, the suspended branch approach could be a more time and cost 
effective method for inducing adelgid infestations for resistance screening of large numbers of candidate trees.

Keywords: adelges tsugae; tsuga canadensis; tsuga caroliniana; tsuga heterophylla; artificial infestation

\section{Introduction}

The hemlock woolly adelgid (Adelges tsugae Annand) (Hemiptera: Adelgidae) is an invasive forest insect pest in eastern North America that was likely transported from Asia on southern Japanese hemlock (Tsuga sieboldii Carr.) nursery stock. It was first discovered in Virginia in the 1950s [1], and since the initial introduction has spread north and south into 19 states [2]. The adelgid feeds on eastern (Tsuga canadensis (L.) Carr.) and Carolina (T. caroliniana Engelm.) hemlock in eastern North America and has caused significant decline and mortality in populations of both species. These ecologically important trees provide food and shelter for wildlife and play key roles in the regulation of stand structure, nutrient cycling, and water relationships in the ecosystems they inhabit [3,4]. The elimination of eastern and Carolina hemlock from these habitats due to the hemlock woolly adelgid is already causing significant shifts in the structure of animal and plant communities and ecological cycles of forests formerly dominated by hemlocks [5].

The hemlock woolly adelgid is characterized by the white woolly masses usually occurring at the base of hemlock needles. The insect has two successful generations per year in eastern North America called the sistens and progrediens [6]. Both occur on hemlock and reproduce by parthenogenesis. A third generation, called the sexupara, is responsible for sexual reproduction in the adelgid's native range but is unsuccessful in North America, likely due to a lack of a susceptible spruce (Picea sp.) host. The sistens generation is present from June to March and gives rise to eggs of the progrediens generation. Progrediens nymphs hatch, settle on hemlock shoots produced the previous year, and mature during April and May. Progrediens adults lay eggs of the sistens generation, the nymphs of which hatch and settle on current-year shoots in May or June before entering an aestival diapause that lasts until October, at which point feeding and development resumes and continues through the winter. Both generations develop through an egg stage, four nymphal instars, and an adult stage. The first nymphal instar, known as a crawler, is the only mobile life stage and disperses actively by crawling or passively by wind, birds, or other animals [7]. Initial infestations occur on healthy hemlock where the adelgid utilizes piercing sucking mouthparts to feed at the base of needles and deplete nutrients from the xylem ray parenchyma cells [8]. Feeding leads to needle loss, bud mortality, reduced new growth, limb dieback, and tree mortality in as few as four years [9], although some trees survive for 10 or more years before succumbing to infestation.

There are currently a number of strategies in various stages of development for managing the impacts of the hemlock woolly adelgid on hemlock ecosystems, including chemical insecticides, biological control, silvicultural management, genetic resource conservation, and the selection, breeding and deployment of adelgid-resistant genotypes. Chemical controls, such as horticultural soaps and oils, and systemic insecticides (imidacloprid, dinotefuran) are utilized primarily in ornamental environments, but also for 
high value trees in forest settings, as single tree injections, soil drenches, or foliar sprays [5]. Biological control is considered to be the most promising long-term solution for adelgid management in forest settings. A number of beetle species that predate on the hemlock woolly adelgid have been identified and released, including Laricobius nigrinus Fender, Sasajiscymnus tsugae (Sasaji and McClure), and Scymnus (Kugelann) species [10]. Silvicultural options include fertilization and irrigation to promote tree health in ornamental settings, and thinning and preemptive logging in forest settings to improve tree health through release, create a microenvironment less favorable for the adelgid, and shift stand composition towards non-preferred species [11]. Ongoing genetic resource conservation efforts have placed more than 2.5 million eastern and Carolina hemlock seeds into long-term preservation and established seed orchards that are being utilized to support efforts, still in the early stages, to breed and deploy hemlock woolly adelgid-resistant hemlock genotypes [12,13].

To date, most emphasis on breeding resistant hemlock genotypes has focused on the production of interspecific hybrids between eastern and Carolina hemlock and putatively adelgid-resistant hemlock species from Asia (T. chinensis (Franchet) Pritzel in Diels, T. diversifolia (Maxim.) Masters, and T. sieboldii Carriére) and western North America (western hemlock, T. heterophylla (Raf.) Sarg.) [14,15]. Also, some studies suggest that vegetative propagation (rooting cuttings and grafts) of eastern and Carolina hemlocks that have survived hemlock woolly adelgid infestations may harbor low-frequency resistance genes $[13,16]$. The long-term success of any resistance breeding effort depends on a number of factors, including the availability of screening protocols that can effectively and efficiently screen the large numbers of trees and identify trees possessing target resistance characteristics for advancement in breeding or field deployment. Current hemlock resistance screening efforts depend almost exclusively on direct infestation of individual plants with standard densities of adelgids [15-18]. While often successful, this approach may not be as time and cost efficient as other approaches. One such alternative approach is the "rain down" method for inducing artificial adelgid infestations on large numbers of hemlock seedlings, cuttings, or grafts en masse, saving time and cost by avoiding the need to treat plants individually. The method involves suspending pest-infested plant material above an arena and allowing the insects to disperse naturally onto target plants placed below, and has been demonstrated to be as effective as direct infestation for inducing artificial infestations of the balsam woolly adelgid (Adelges piceae Ratzburg) for resistance screening in Fraser fir (Abies fraseri (Pursch) Poir.) [19].

Jetton et al. [20] adapted the "rain down” approach for use with hemlock and evaluated the density and distribution patterns of hemlock woolly adelgid crawlers dispersing from suspended branches, but the utility of the method for inducing infestations on hemlock seedlings has not been thoroughly investigated. Furthermore, the timing of peak and complete crawler dispersal from adelgid infested hemlock branches onto target seedlings is not clear. The objectives of the study reported here are to: (1) determine the timing of crawler dispersal over a 10 day period from hydrated and non-hydrated cut hemlock branches; and (2) compare a suspended branch ("rain down") infestation technique with two levels of a direct infestation technique in terms of resulting adelgid density on target seedlings. 


\section{Materials and Methods}

\subsection{Crawler Dispersal Experiments}

Laboratory experiments were conducted to compare the abundance and timing of progrediens crawler dispersal from ovisacs on hydrated and non-hydrated cut branch tips. Branches infested with sistens adults and progrediens eggs were collected from eastern hemlock in Asheville, NC, USA (latitude, longitude: 35.611966, -82.562181), placed on artificial ice in an insulated container, and shipped overnight to Raleigh, NC, USA (latitude, longitude: 35.783948, -78.680387) on 13 February 2012. The cut ends of all branches were temporarily stored in buckets of tap water at room temperature for 9 days until used in the experiments. Sistens adult and progrediens egg densities were estimated by counting life stages on 52, $4 \mathrm{~cm}$ long hemlock branch tips cut from the source material. There were approximately $3.95 \pm 0.38$ ovisacs per $\mathrm{cm}$ branch and $14.15 \pm 1.42$ eggs per ovisac on the source material. Thirty additional $10 \mathrm{~cm}$ long infested branch tips were cut for use in the experiment and grouped into 15 matched pairs. Each branch was placed bottom-side down on a $25 \times 25 \mathrm{~cm}$ section of poultry wire centered on top of a $1000 \mathrm{~cm}^{3}$ paperboard box (Michael's Stores Inc., Irving, TX, USA) with the bottom and top sides removed. A $10 \times 10 \mathrm{~cm}$ sticky sheet of white paper printed with $1 \mathrm{~cm}^{2}$ grid lines was coated with an aerosol spray formulation of Tanglefoot ${ }^{\circledR}$ Tangle-Trap Insect Coating (Contech Enterprises, Victoria, BC, Canada) and placed under the open bottom side of each cube. One branch tip in each matched pair was randomly assigned to a water hydration treatment in which the cut end was inserted into a plastic floral water pick (Panacea Floral Supplies, Columbus, OH, USA) filled with tap water. The other branch in each pair did not receive a water pick. Water levels in the picks were checked daily and refilled before the pick was half empty. Branches in each matched pair were located adjacent to one another and pairs were arranged in rows on a table in a laboratory maintained at $22{ }^{\circ} \mathrm{C}$. Examination of the ovisacs nine days prior to day 1 of these experiments (13 February 2012) indicated that egg laying had just begun, and crawler density on day 1 was low $\left(<0.13\right.$ per $\mathrm{cm}^{2}$, Figure 1$)$; thus, the start of these experiments coincided very closely with the start of crawler emergence.

Branches were deployed over the sticky sheets for 10 days (22 February-2 March 2012) in two simultaneous experiments. The first was a daily crawler dispersal study where sticky sheets were collected and replaced daily for five matched branch pairs. The second was a total crawler dispersal study where sticky sheets were collected only on the 10th day for the other 10 matched pairs. The density of progrediens crawlers that fell from the suspended branch onto each sticky sheet was estimated using image analysis. Each sticky sheet was cleared of minimal amounts of needles and debris and scanned using a Zeutschel OS 12000 Bookcopy overhead scanner (Zeutschel GmbH, Tübingen-Hirschau, Germany). Resulting images were saved as TIFF files and analyzed using the software Image $\mathrm{J}$ version 1.48 (National Institutes of Health, Bethesda, MD, USA). Pictures were enhanced by 0.4\%, converted to binary, and the total number of crawlers for each sheet was determined using the Cell Counter function. 


\subsection{Artificial Infestation Experiments}

\subsubsection{Source Material}

Three experiments were conducted in March 2012, May 2012, and March 2013 to compare a suspended branch technique with direct infestation techniques of infesting hemlock seedlings with the hemlock woolly adelgid. Eggs of the progrediens and sistens generations were used to infest seedlings in the March and May experiments, respectively. Immediately prior to each experiment, infested branches were collected using pole pruners from eastern hemlocks near Marion, NC, USA (latitude, longitude: 35.606825, -82.100354, March 2012 experiment), Petros, TN, USA (latitude, longitude: 36.09395, -84.409075, March and May 2012 experiments), and Asheville, NC, USA (latitude, longitude: 35.611966,-82.562181, March 2013 experiment). Infested branches 40 and $20 \mathrm{~cm}$ long were cut for suspended branch treatments and direct infestation treatments, respectively. The cuts ends of the $40 \mathrm{~cm}$ branches were placed in tap water in $11.4 \mathrm{~L}$ plastic buckets and held at $13-18{ }^{\circ} \mathrm{C}$ until used in experiments. The $20 \mathrm{~cm}$ branches were hydrated using a method similar to that of Butin et al. [17] in which the cut end and lower stem of the branch were pressed through a layer of Parafilm ${ }^{\circledR}$ (Pechiney Plastic Packaging Company, Chicago, IL, USA) covering the top of a $25 \mathrm{~mL}$ Falcon ${ }^{\mathrm{TM}}$ centrifuge tubes (Corning Inc. Life Sciences, Tewksbury, MA, USA) filled with tap water. For each experiment, mean ovisac and egg densities were estimated from a sample of 15 branches cut from the infested branch material (values reported in the respective infestation sections).

Bare root, 2-4 year old seedlings of eastern, western and Carolina hemlock were obtained from Pikes Peak Nursery (Penn Run, PA, USA), Weyerhaeuser Forest Nursery (Aurora, OR, USA) and Foggy Mountain Nursery (Lansing, NC, USA), respectively. In January 2012, seedlings were potted in Fafard ${ }^{\circledR}$ 3B growing mix (Sun Gro Horticulture, Agawam, MA, USA) in 6 L plastic pots, treated with 15 g of Multicoat 15-16-17 fertilizer (Haifa Group, Altamont Springs, FL, USA) on the soil surface, and watered with tap water. Seedlings were watered regularly and maintained in a greenhouse with a maximum temperature of $21{ }^{\circ} \mathrm{C}$ until March 2012 when they were moved outside for use in experiments. Mean \pm SE basal stem caliper of the eastern, Carolina, and western hemlock seedlings in 2012 was $9.85 \pm 0.33 \mathrm{~mm}, 9.89 \pm 0.33 \mathrm{~mm}$, and $7.95 \pm 0.16 \mathrm{~mm}$, respectively, and mean $\pm \mathrm{SE}$ height was $48.60 \pm 1.10 \mathrm{~cm}, 74.06 \pm 1.96$, and $46.30 \pm 1.15 \mathrm{~cm}$, respectively.

\subsubsection{Experimental Design}

The March and May 2012 experiments were conducted at the North Carolina State University/North Carolina Department of Agriculture \& Consumer Services Mountain Research Station in Waynesville, NC, USA $\left(35.487319^{\circ} \mathrm{N},-82.966883^{\circ} \mathrm{W}\right)$. In each experiment, seedlings were arranged in a randomized complete block design of four blocks each containing four $1 \mathrm{~m}^{2}$ treatment plots. Seedlings were randomly assigned to one of four infestation treatments: (1) suspended branch; (2) direct high; (3) direct low; and (4) control. In the control treatment, no adelgid ovisacs or eggs were applied to any of the seedlings, and these plots were included to evaluate whether adelgid crawlers were travelling from one treatment plot to another. Nine seedlings, three of each species, were placed in each $1 \mathrm{~m}^{2}$ treatment plot in a three-by-three, Latin square pattern such that each row and column contained one seedling of each species. A $1 \mathrm{~m}^{3}$ cubic frame made of $2 \mathrm{~cm}$ diameter schedule 40 PVC (polyvinyl chloride) pipe 
was placed over the nine seedlings in each plot. The four vertical sides of the frame were covered with $0.15 \mathrm{~mm}$ clear plastic sheeting to deter movement of adelgid crawlers out of each plot. The sheeting was secured to the frame with metal binder clips. Seedlings and frames were placed on a concrete floor in a non-climate controlled, concrete block building that sheltered plots from rain, direct sunlight, and wind.

The design and implementation of the March 2013 experiment was similar to the 2012 experiments with the following exceptions: (1) due to minimal infestation of control seedlings in 2012, the control treatment was included in only two of the four experimental blocks; (2) four seedlings of each of two species (eastern and Carolina hemlock) were randomly assigned to and arranged in each $1 \mathrm{~m}^{2}$ treatment plot; (3) seedling blocks were infested inside a doublewide trailer at $10-20^{\circ} \mathrm{C}$ at the Bent Creek Experimental Forest, Asheville, NC, USA (latitude, longitude: 35.612529, -82.563332); and (4) after infestation, seedlings were moved outdoors onto the forest floor beneath a contiguous hardwood forest canopy.

\subsubsection{March 2012 Progrediens Infestation}

Artificial infestation treatments with progrediens eggs were applied on 7 March 2012. In the suspended branch treatment, a $1 \mathrm{~m}^{2}$ section of poultry wire was placed over the top of the PVC frame and secured with plastic cable ties. Forty infested branches, $40 \mathrm{~cm}$ in length, including the main branch and side branches, were placed bottom-side down on top of the poultry wire in four rows of 10 branches. A second section of poultry wire was placed over the branches to hold them in place. In the direct infestation treatments, the $20 \mathrm{~cm}$ infested branches hydrated in centrifuge tubes (described previously) were placed in contact with the seedling foliage, either by securing the centrifuge tub into the soil near the base of the seedling (short seedlings) or attaching it to the branches with a plastic cable tie (taller seedlings). Approximately $15 \mathrm{~cm}$ of branch, including the main branch and side branches, was exposed to the seedlings. Each seedling was treated with three infested branches in the direct high treatment and with one infested branch in the direct low treatment. Based on estimates of $19.17 \pm 1.59$ adelgid ovisacs per $\mathrm{cm}$ of branch length and $40.50 \pm 2.80$ eggs per ovisac on the infested branches, approximately 1.2 million, 312,000, and 104,000 progrediens eggs per $\mathrm{m}^{2}$ were applied to each plot in the suspended branch, direct high, and direct low infestation treatments respectively. In the control treatment, no infested branches were placed on or above the seedlings.

All infested branches were removed from the seedlings after 9 days on 16 March 2012. Seedlings were placed outside in direct sunlight on top of a black ground fabric weed barrier, and arranged in the same block and plot positions under which they were infested indoors. The sides of each $1 \mathrm{~m}^{2}$ square outdoor treatment plot were formed by driving four metal T-posts into the ground (above ground height $1 \mathrm{~m}$ ) at the corners and covering the vertical sides with a double layer of landscape fabric. Seedlings were irrigated with a sprinkler through the summer and fall as needed and remained in the plots until counts of adelgid sistens nymphs were made in November.

\subsubsection{May 2012 Sistens Infestation}

Artificial infestation treatments with sistens eggs were initiated on 11 May 2012. The location, experimental design, seedling species and arrangement, and plot construction were identical to that used in the March progrediens experiment. The control seedlings in the March experiment did not become infested so they were reused in the control treatments of the May experiment. Based on estimates of 
$14.39 \pm 1.93$ adelgid ovisacs per cm of branch length and $6.57 \pm 0.64$ eggs per ovisac on the infested branches, approximately 147,000, 37,000, and 12,000 sistens eggs were applied to each plot in the suspended branch, direct high, and direct low infestation treatments, respectively. Infested branches were introduced and removed after 14 days on 25 May 2012. Seedlings were moved outdoors onto landscape fabric, adjacent to the seedlings of the March experiment and using the same plot construction, layout, and irrigation regime.

\subsubsection{March 2013 Progrediens Infestation}

A second infestation experiment using progrediens eggs was initiated on 26 March 2013. Based on estimates of $9.45 \pm 1.13$ adelgid ovisacs per cm of branch length and $77.69 \pm 5.38$ eggs per ovisac on the infested branches, approximately 1.1 million, 252,000, and 84,000 progrediens eggs per $\mathrm{m}^{2}$ were applied to each plot in the suspended branch, direct high, and direct low infestation treatments respectively. Plots were infested as described in the March 2012 progrediens infestation experiment. Infested branches were removed from plots after 10 days on 5 April 2013 and seedlings were moved outdoors onto the forest floor beneath a contiguous hardwood forest canopy. The sides of each $1 \mathrm{~m}^{2}$ square outdoor treatment plot were formed by driving four metal T-posts into the ground (above ground height $1 \mathrm{~m}$ ) at the corners and covering the vertical sides with a double layer of landscape fabric. Seedlings were irrigated with a hose and spray nozzle as needed through November 2013.

\subsubsection{Assessment of Adelgid Densities on Seedlings}

To assess resulting adelgid densities on seedlings infested in the March and May 2012 experiments, branch tips were collected from all seedlings on 2 November 2012. Five $10 \mathrm{~cm}$ long branch tips (one terminal and four lateral tips) of the current year shoot growth were collected per seedling. Samples were transported on ice and stored in a walk-in cooler at the North Carolina State University Camcore lab at $6{ }^{\circ} \mathrm{C}$ until processed. Samples were examined using a dissecting microscope and the number of live adelgid sistens nymphs on each branch tip was recorded. Live nymphs were distinguished from dead nymphs by the presence of recently-excreted wool on the dorsal surface of the insect. For seedlings infested in the March 2013 experiment, counts of woolly progrediens (settled on shoot growth of the previous year) and sistens (settled on current-year shoot growth) ovisacs were made on 10 June 2013 and 25 November 2013, respectively. Ovisacs were counted on five $10 \mathrm{~cm}$ branch tips (one terminal and four laterals) without removing the branches from the seedlings.

\subsubsection{Data Analysis}

To determine the effect of hydration versus no hydration on crawler dispersal from hemlock twigs, paired $t$-tests using the TTEST procedure of SAS 9.4 [21] were performed to compare daily crawler dispersal among the five matched pairs in the daily crawler dispersal study and overall crawler dispersal among the 10 matched pairs in the total crawler dispersal study. Seedling infestation density data from the 2012 and 2013 artificial infestation experiments were analyzed by analysis of variance using the GLIMMIX (generalized linear mixed model) procedure of SAS 9.4, assuming a Poisson distribution and log link function. Data from the March 2012 progrediens infestation and May 2012 sistens infestation 
experiments were combined for analysis. For the 2012 data, the ANOVA model tested the main effects of block, infestation treatment, hemlock species, and infestation month and all two-way interactions between treatment, species, and month on the density of hemlock woolly adelgids per $10 \mathrm{~cm}$ twig sample. For data from the 2013 experiment, the ANOVA model tested the main effects of block, infestation treatment, and hemlock species and the treatment by species interaction on the density of hemlock woolly adelgids per $10 \mathrm{~cm}$ twig sample three and eight months after artificial infestation treatments. Where significant effects were found, mean comparison analyses were performed using Tukey's studentized range test at $\alpha=0.05$, utilizing the slice option to compare within group (i.e., month or species) means for significant interaction effects. In both experiments, data from the control treatments were not included in the analysis due to very low mean hemlock woolly adelgid infestation densities in these treatments (0.09 \pm 0.03 in 2012 and $0.0001 \pm 0.02$ in 2013). All means reported are least square means and all measures of variation reported are standard errors.

\section{Results}

\subsection{Crawler Dispersal Experiments}

The daily dispersal of hemlock woolly adelgid crawlers reached a peak on day 5 for both hydrated and non-hydrated hemlock twigs (Figure 1). From this peak, crawler dispersal from non-hydrated twigs continued a steady decline through the final day of the experiment (day 10), while dispersal from hydrated twigs declined from days 5 to 8 before increasing on days 9 and 10 . Crawler dispersal on each individual day did not differ significantly between the hydration treatments. In the companion experiment, total crawler dispersal was significantly higher from non-hydrated compared to hydrated hemlock twigs ( $t=3.47, d f=9, p=0.0070$ ) (Figure 2), a non-significant trend that was also apparent in the 10 day means for hydrated $(135.7 \pm 32.5)$ and non-hydrated $(145.1 \pm 33.3)$ twigs in the daily dispersal experiment.

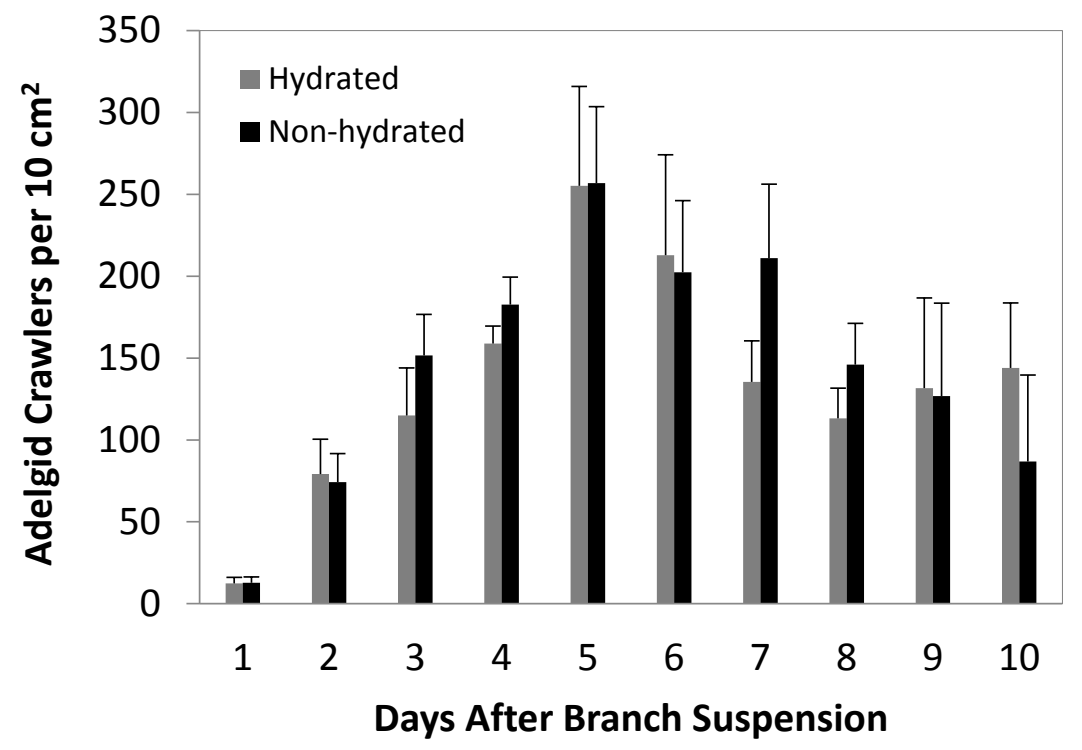

Figure 1. Daily dispersal, over a 10-day period, of hemlock woolly adelgid progrediens crawlers from hydrated and non-hydrated $10 \mathrm{~cm}$ long sistens infested eastern hemlock twigs. 


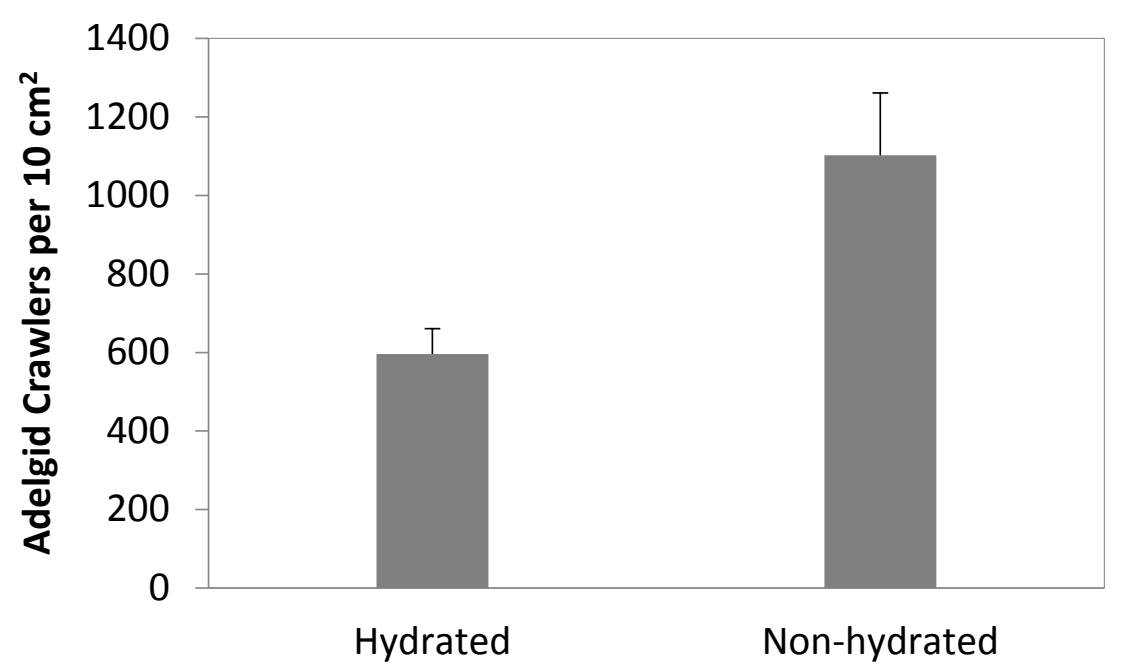

Treatment

Figure 2. Total 10 day dispersal of hemlock woolly adelgid progrediens crawlers from hydrated and non-hydrated $10 \mathrm{~cm}$ long sistens infested eastern hemlock twigs.

\subsection{Artificial Infestation Experiments}

Hemlock woolly adelgid densities on seedlings in the 2012 artificial infestation experiments were significantly affected by block $(F=6.52, d f=3, p=0.0003)$, month $(F=41.73, d f=1, p<0.0001)$ and the interaction of treatment by month $(F=5.86, d f=2, p=0.0034)$. Adelgid sistens densities measured in November were significantly higher on seedlings infested in March with progrediens crawlers compared to those infested in May with sistens crawlers (Table 1). Following March infestations, the highest adelgid densities resulted from the direct high treatment, followed by the direct low and suspended branch treatments, but adelgid densities resulting from May infestations did not differ by treatment (Table 1) Significant differences were not detected for the treatment $(F=2.00, d f=2$, $p=0.1387)$ and species $(F=2.45, d f=2, p=0.0885)$ main effects or the month by species $(F=2.50$, $d f=2, p=0.2252)$ and treatment by species $(F=0.97, d f=4, p=0.4244)$ interactions.

\subsection{Artificial Infestation Experiment}

In June 2013, three months after infestation treatments were applied in March, hemlock woolly adelgid progrediens densities on seedlings were significantly affected by block $(F=3.52, d f=3$, $p=0.0184)$, treatment $(F=14.49, d f=2, p=<0.0001)$, species $(F=57.29, d f=1, p<0.0001)$ and the interaction of treatment by species $(F=4.17, d f=2, p=0.0187)$. Overall, adelgid densities were higher on eastern hemlock than on Carolina hemlock, and on both species the suspended branch and direct high infestation treatments resulted in higher infestation levels than the direct low treatment (Table 2). 
Table 1. Mean ( \pm SE) hemlock woolly adelgid densities (sistens nymphs per $10 \mathrm{~cm}$ twig sample) on hemlock seedlings in November 2012, by main effect (infestation treatment, hemlock species, and treatment month) and interactions of main effects by month and hemlock species.

\begin{tabular}{|c|c|c|c|c|c|c|}
\hline \multirow[b]{2}{*}{ Main Effect } & \multirow{2}{*}{$\begin{array}{c}\text { Main Effect } \\
\text { Alone } \\
\end{array}$} & \multicolumn{2}{|c|}{ Main Effect $\times$ Month } & \multicolumn{3}{|c|}{ Main Effect $\times$ Hemlock Species } \\
\hline & & March & May & Eastern & Carolina & Western \\
\hline \multicolumn{7}{|l|}{ Treatment } \\
\hline Control & $0.09( \pm 0.03) *$ & $0.09( \pm 0.03) *$ & $0.09( \pm 0.03) *$ & $0.10( \pm 0.06) *$ & $0.13( \pm 0.08) *$ & $0.05( \pm 0.02) *$ \\
\hline Direct Low & $0.40( \pm 0.08)^{\mathrm{a}}$ & $1.01( \pm 0.16)^{b}$ & $0.16( \pm 0.06)^{\mathrm{a}}$ & $0.26( \pm 0.09)^{\mathrm{a}}$ & $0.61( \pm 0.16)^{\mathrm{a}}$ & $0.41( \pm 0.13)^{\mathrm{a}}$ \\
\hline Direct High & $0.65( \pm 0.11)^{\mathrm{a}}$ & $1.76( \pm 0.22)^{\mathrm{a}}$ & $0.23( \pm 0.07)^{\mathrm{a}}$ & $0.55( \pm 0.16)^{\mathrm{a}}$ & $0.75( \pm 0.18)^{\mathrm{a}}$ & $0.65( \pm 0.17)^{\mathrm{a}}$ \\
\hline Suspended Branch & $0.43( \pm 0.07)^{\mathrm{a}}$ & $0.53( \pm 0.12)^{c}$ & $0.34( \pm 0.10)^{\mathrm{a}}$ & $0.48( \pm 0.14)^{\mathrm{a}}$ & $0.61( \pm 0.15)^{a}$ & $0.27( \pm 0.10)^{\mathrm{a}}$ \\
\hline \multicolumn{7}{|l|}{ Hemlock Species } \\
\hline Eastern & $0.41( \pm 0.09)^{\mathrm{a}}$ & $1.11( \pm 0.18)^{\mathrm{a}}$ & $0.15( \pm 0.06)^{a}$ & & & \\
\hline Carolina & $0.65( \pm 0.10)^{\mathrm{a}}$ & $1.22( \pm 0.18)^{a}$ & $0.35( \pm 0.09)^{\mathrm{a}}$ & & & \\
\hline Western & $0.41( \pm 0.08)^{\mathrm{a}}$ & $0.69( \pm 0.14)^{a}$ & $0.25( \pm 0.08)^{\mathrm{a}}$ & & & \\
\hline \multicolumn{7}{|l|}{ Month } \\
\hline March & $0.98( \pm 0.10)^{\mathrm{a}}$ & & & & & \\
\hline May & $0.24( \pm 0.05)^{b}$ & & & & & \\
\hline
\end{tabular}

Note: Means within each month/variable/effect group followed by different letters are significantly different at $\alpha \leq 0.05$, Tukey’s HSD test; * The control treatment was excluded from statistical analysis.

In November 2013, eight months after the infestation treatments, hemlock woolly adelgid densities on seedlings were still significantly affected by block $(F=8.19, d f=3, p=0.0002)$ and treatment ( $F=5.40, d f=2, p=0.0077)$, but species $(F=0.00, d f=1, p=0.9780)$ and the treatment by species interaction ( $F=0.88, d f=2, p=0.4194$ ) were no longer significant. Seedlings in the direct low and direct high treatments supported higher adelgid densities than the suspended branch treatment, and the rank order of the treatments was opposite of that seen in June, with seedlings in the direct low and suspended branch treatments supporting the highest and lowest adelgid densities, respectively (Table 2).

\section{Discussion}

\subsection{Crawler Dispersal}

The results from the crawler dispersal experiment suggest that at least one peak in crawler dispersal from eastern hemlock branches is accomplished within the first 10 days of emergence. Although crawlers had begun to disperse before day 1 of the experiment, examination of the ovisacs nine days prior to day 1 (February 13, 2012) indicated that egg laying had just begun, and crawler density on day 1 was low $\left(<0.13\right.$ per $\left.\mathrm{cm}^{2}\right)$; thus, the start of the experiment coincided very closely with the start of crawler emergence. The dispersal of crawlers likely continued after the last day of the experiment as indicated by the increase in dispersal from hydrated branches on days 9 and 10. Although crawler dispersal had not ceased, we ended the experiment after day 10 due to deterioration of the non-hydrated branches. Our data are consistent with those of Butin et al. [17] which suggest that the majority of crawlers leave the branches within 2 weeks of initial emergence. 
Table 2. Mean ( \pm SE) infestation density of hemlock woolly adelgids (per $10 \mathrm{~cm}$ twig sample) on eastern and Carolina hemlock seedlings three and eight months after exposure to sistens crawlers in March 2013.

\begin{tabular}{ccc}
\hline & June 2013 Adelgid Density (Progrediens) & November 2013 Adelgid Density (Sistens) \\
\hline Treatment & $0.0002( \pm 0.03)^{*}$ & $0.05( \pm 0.05)^{*}$ \\
Control & $7.77( \pm 0.46)^{\mathrm{b}}$ & $3.96( \pm 0.46)^{\mathrm{a}}$ \\
Direct Low & $10.22( \pm 0.57)^{\mathrm{a}}$ & $2.94( \pm 0.39)^{\mathrm{a}}$ \\
Direct High & $12.13( \pm 0.67)^{\mathrm{a}}$ & $1.76( \pm 0.29)^{\mathrm{b}}$ \\
Suspended Branch & & \\
Hemlock Species & $12.71( \pm 0.52)^{\mathrm{a}}$ & $2.75( \pm 0.26)^{\mathrm{a}}$ \\
Eastern & $7.68( \pm 0.40)^{\mathrm{b}}$ & $2.74( \pm 0.32)^{\mathrm{a}}$ \\
Carolina & & \\
Treatment*Species & & \\
Eastern hemlock & $0.02( \pm 0.05)^{*}$ & $3.04( \pm 0.04)^{*}$ \\
Control & $9.57( \pm 0.79)^{\mathrm{b}}$ & $3.38( \pm 0.47)^{\mathrm{a}}$ \\
Direct Low & $12.10( \pm 0.86)^{\mathrm{a}}$ & $1.54( \pm 0.31)^{\mathrm{a}}$ \\
Direct High & $17.71( \pm 1.02)^{\mathrm{a}}$ & \\
Suspended Branch & $8.63( \pm 0.73)^{\mathrm{a}}$ & $0.08( \pm 0.08)^{*}$ \\
Carolina hemlock & $0.0001( \pm 0.03)^{*}$ & $4.00( \pm 0.77)^{\mathrm{a}}$ \\
Control & $6.31( \pm 0.60)^{\mathrm{b}}$ & $1.56( \pm 0.77)^{\mathrm{a}}$ \\
Direct Low & $8.67( \pm 0.76)^{\mathrm{a}}$ \\
Direct High & &
\end{tabular}

Note: Means within each month/variable/effect group followed by different letters are significantly different at $\alpha \leq 0.05$, Tukey's HSD test; * The control treatment was excluded from statistical analysis.

A greater density of crawlers dispersed from non-hydrated branches than hydrated branches, indicated by the total dispersal after 10 days as well as the 10 day means. One possible explanation for this is that crawlers may have settled to feed on (rather than disperse from) hydrated branches due to their superior host quality compared to non-hydrated branches; a pattern that is consistent with what is known about the interaction of host quality and population dynamics for this insect [22]. However, we did not examine source branches for settling of crawlers and cannot confirm this is what happened in this experiment. Nonetheless, our data suggest that when fresh, infested hemlock material is collected and applied near the time of initial egg hatch, better infestation pressure may be accomplished by using non-hydrated infested branches. Not hydrating the branches reduces handling and time preparing the trees for evaluation, thus making the screening effort more efficient and less time consuming.

\subsection{Infestations}

In 2012, we observed greater adelgid fecundity on the source material in March than May, which resulted in higher density infestations on target seedlings in March. Other studies have also observed greater numbers of progrediens eggs per ovisac or unit branch length in March than sistens eggs in May [6,17,20]. Unfortunately, the 2012 infestations resulted in extremely low adelgid densities ( $<2$ adelgids per $10 \mathrm{~cm}$ ), levels that are likely too low to result in significant negative impacts on seedling growth and would complicate determinations of resistance or susceptibility in a breeding program. 
Early studies of the adelgid suggested that infestations densities of greater than four adelgids per cm branch are necessary to cause tree damage [22], but the actual threshold density required to negatively affect tree growth and health are not known. We suspect the low infestation densities recorded may have been the result of light conditions in the outdoor plots rather than a failure of the artificial infestation methods. When moved outdoors from the concrete block building where the infestation treatments were applied, the seedlings were placed in direct sunlight. Ongoing research indicates a strong negative correlation between increasing levels of sunlight exposure and adelgid infestation densities on potted hemlock seedlings, with seedlings maintained under full light exposure supporting extremely low ( $<1$ adelgid per $10 \mathrm{~cm}$ ) densities [23]. This was addressed in the 2013 infestation experiment by placing infested seedlings under a deciduous forest canopy instead of direct sunlight when moved outside.

\subsection{Infestations}

In June 2013, three months after exposure to the infestation treatments, progrediens densities on hemlock seedlings ranged from 7 to 12 adelgids per $10 \mathrm{~cm}$ across all treatments and were on average 12 times higher than those recorded in the 2012 experiment. This suggests that maintaining seedlings under the shaded conditions of the deciduous canopy cover improved the initial infestation on the seedlings. Among the infestation treatments, the suspended branch and direct high infestation techniques resulted in higher progrediens infestation densities than the direct low treatment. Although the suspended branch and direct high treatments did not differ significantly for either hemlock species, they did differ in rank order. The suspended branch provided the highest infestation levels on eastern hemlock and direct high provided marginally higher infestations on Carolina hemlock. Overall, these results indicate that all three treatments tested can result in successful progrediens infestations on potted hemlock seedlings and higher infestation levels can be expected using the suspended branch and direct high techniques. However, as with the 2012 infestation experiment, it remains unclear if these infestation levels are suitable for resistance testing. In a previous test of the suspended branch treatment alone, this method produced progrediens infestation densities of 4 to 7 adelgids per $1 \mathrm{~cm}$ of branch on Carolina hemlock seedlings [19], at and above the damage threshold level suggested by McClure [22]. Why the suspended branch technique failed to produce suitable infestation densities in the current study is difficult to say. Although not quantified, in both the 2012 and 2013 experiments, seedlings were noted to be in good health and had ample flushes of the most recent shoot growth on which the progrediens (previous year's growth) and sistens (current year's growth) could settle. The results suggest that additional research is needed on the consistency of the artificial infestation environment and the influence of the health and quality of the hemlock seedlings and hemlock woolly adelgids used for infestations.

In November 2013, eight months after exposure to the infestation treatments, the overall infestation densities on seedlings in the study dropped significantly and the rank order of treatments had shifted. The drop in overall infestation level was not surprising since it is well established that adults of the progrediens generation are less fecund than those of the sistens generation as noted above. However, the change in rank order among the treatments, with the highest sistens infestation densities in the direct low treatment, was not expected. We suspect this may have resulted from increased intraspecific competition among adults of the progrediens generation on the suspended branch and direct high 
treatment seedlings, leading to lower fecundity and production of sistens eggs. Intraspecific competition may have been less pronounced on the more lightly infested direct low treatment seedlings and the fecundity and production of sistens eggs higher for the progrediens adults on these seedlings. These results illustrate the importance of defining the length of time over which seedlings will be evaluated in resistance tests, as well as accounting for the density of both progrediens and sistens crawlers if evaluating seedlings across multiple adelgid generations.

Upon initial seedling evaluations in June 2013, progrediens infestation levels on eastern hemlock seedlings were significantly higher than those on Carolina hemlock seedlings. This is consistent with what was observed in studies by Jetton et al. [18] and Oten [24], where artificially infested potted and planted, respectively, Carolina hemlock seedlings supported low level initial adelgid densities that were similar to putatively adelgid-resistant western hemlock while those on eastern hemlock were much higher. Results such as these have been used to support the hypothesis that, due to its close genetic relationship to adelgid-resistant hemlock species native to Asia, Carolina hemlock may harbor some level of resistance or tolerance to hemlock woolly adelgid relative to eastern hemlock. However, despite differences in progrediens levels in June, this trend did not hold and following seedling evaluations in November 2013 sistens infestation levels did not differ between the hemlock species. Furthermore, Jetton et al. [20] demonstrated that initial progrediens infestation densities as high as 7 adelgids per $\mathrm{cm}$ branch length can be achieved on Carolina hemlock. With such mixed results across multiple studies, drawing conclusions on the adelgid resistance or tolerance status of Carolina hemlock based on short-term seedling infestation studies is tenuous.

\section{Conclusions}

The studies reported here build upon preliminary investigations into the utility of the suspended branch technique for artificially infesting hemlock seedlings reported by Jetton et al. [20]. The crawler dispersal experiment indicated that crawler emergence peaks within the first two weeks on non-hydrated branches and a second smaller or equal size peak may occur on hydrated branches, suggesting that a 10 to 14 day period is likely sufficient for target seedlings to be exposed to adelgid-infested source material. Additionally, this experiment suggests that using non-hydrated branches is likely to provide greater infestation pressure. The infestation experiments indicate that greater infestation pressure can also be expected when using progrediens crawlers compared to sistens crawlers, and that the suspended branch can induce the same or higher adelgid densities on seedlings as direct infestation techniques. Assuming an initial investment in infrastructure, the suspended branch approach could be a more time and cost effective method for inducing adelgid infestations for resistance screening of large numbers of trees. Further research should focus on identifying the ideal temperature, light, irrigation, and initial infestation densities required to maintain adelgid infestations on seedlings for longer durations, the adelgid density thresholds required for inducing seedling responses and decline, and the physical and/or chemical seedling characteristics other than adelgid infestation density that are the appropriate indicators of genotype resistance or susceptibility. 


\section{Acknowledgments}

The authors thank Kaleb Rathbone and the staff of the North Carolina State University/North Carolina Department of Agriculture \& Consumer Services Mountain Research Station in Waynesville, NC for facilities and technical support; Andy Whittier (NCSU-Camcore), Lia Campbell (NCSU-Camcore), Andy Tait (NCSU-Camcore/USFS-SRS), and Corrine Fretwell (UNC-Asheville) for technical assistance; Brent Galloway and Joseph Loudermilk for assistance with locating adelgid source material for infestations; and Fred Hain for comments on earlier drafts of this manuscript. This project was funded by USFS-SRS Cooperative Agreement 11-CA-11330129-064 to the Camcore program at NC State University.

\section{Author Contributions}

Zaidee Powers, Albert Mayfield, and Robert Jetton contributed to the study design, study execution, data analysis, and manuscript preparation. John Frampton contributed to the data analysis and manuscript preparation.

\section{Conflicts of Interest}

The authors declare no conflict of interest.

\section{References}

1. Souto, D.; Luther, T.; Chianese, B. Past and current status of HWA in eastern and Carolina hemlock stands. In Proceedings of the First Hemlock Woolly Adelgid Review, Charlottesville, VA, USA, 12 October 1995; Salom, S.M., Tigner, T.C., Reardon, R.C., Eds.; USDA Forest Service: Morgantown, WV, USA, 1996; pp. 9-15.

2. Counties with Established HWA Populations 2012. Available online: http://na.fs.fed.us/fhp/hwa/ maps/2011.pdf (accessed on 24 March 2015).

3. Evans, R.A.; Johnson, E.; Shreiner, J.; Ambler, A.; Battles, J.; Cleavitt, N.; Fahey, T.; Sciascia, J.; Pehek, E. Potential impacts of hemlock woolly adelgid (Adelges tsugae) on eastern hemlock (Tsuga canadensis) ecosystems. In Proceedings of the First Hemlock Woolly Adelgid Review, Charlottesville, VA, USA, 12 October 1995; Salom, S.M., Tigner, T.C., Reardon, R.C., Eds.; USDA Forest Service: Morgantown, WV, USA, 1996; pp. 42-57.

4. Ellison, A.M.; Bank, M.S.; Clinton, B.D.; Colburn, E.A.; Elliott, K.J.; Ford, C.R.; Foster, D.R.; Kloeppel, B.D.; Knoepp, J.D.; Lovett, G.M.; et al. Loss of foundation species: Consequences for the structure and dynamics of forested ecosystems. Front. Ecol. Environ. 2005, 3, 479-486.

5. Vose, J.M.; Wear, D.N.; Mayfield III, A.E.; Nelson, C.D. Hemlock woolly adelgid in the southern Appalachians: Control strategies, ecological impacts, and potential management responses. For. Ecol. Manag. 2013, 291, 209-219.

6. McClure, M.S. Evidence of a polymorphic life cycle in the hemlock woolly adelgid, Adelges tsugae (Homoptera: Adelgidae). Ann. Entomol. Soc. Am. 1989, 82, 50-54.

7. McClure, M.S. Role of wind, birds, deer, and humans in the dispersal of hemlock woolly adelgid (Homoptera: Adelgidae). Environ. Entomol. 1990, 19, 36-43. 
8. Young, R.F.; Shields, K.S.; Berlyn, G.P. Hemlock woolly adelgid (Homoptera: Adelgidae): Stylet bundle insertion and feeding sites. Ann. Entomol. Soc. Am. 1995, 88, 827-835.

9. Havill, N.P.; Vieira, L.C.; Salom, S.M. Biology and Control of Hemlock Woolly Adelgid; USDA Forest Service: Morgantown, WV, USA, 2014; p. 21.

10. Onken, B.P.; Reardon, R.C. An overview and outlook for biological control of hemlock woolly adelgid. In Implementation and Status of Biological Control of the Hemlock Woolly Adelgid; Onken, B., Reardon, R., Eds.; USDA Forest Service: Morgantown, WV, USA, 2011; pp. 222-228.

11. Ward, J.S.; Montgomery, M.E.; Cheah, C.A.S.J.; Onken, B.; Cowles, R.S. Eastern Hemlock Forests: Guidelines to Minimize the Impacts of Hemlock Woolly Adelgid; USDA Forest Service: Morgantown, WV, USA, 2004; p. 28.

12. Jetton, R.M.; Whittier, W.A.; Dvorak, W.S.; Rhea, J. Conserved ex situ genetic resources of eastern and Carolina hemlock: Eastern North American conifers threatened by the hemlock woolly adelgid. Tree Plant. Notes 2013, 56, 59-71.

13. Oten, K.L.F.; Merkle, S.A.; Jetton, R.M.; Smith, B.C.; Talley, M.E.; Hain, F.P. Understanding and developing resistance in hemlocks to the hemlock woolly adelgid. Southeast. Nat. 2014, 13, 147-167.

14. Bentz, S.E.; Riedel, L.G.H.; Pooler, M.R.; Townsend, A.M. Hybridization and self-compatibility in controlled pollination of eastern North American and Asian hemlock (Tsuga) species. J. Arboric. 2002, 28, 200-205.

15. Montgomery, M.E.; Bentz, S.E.; Olsen, R.T. Evaluation of hemlock (Tsuga) species and hybrids for resistance to Adelges tsugae (Hemiptera: Adelgidae) using artificial infestation. J. Econ. Entomol. 2009, 102, 1247-1254.

16. Caswell, T.; Casagrande, R.; Maynard, B.; Preisser, E. Production and evaluation of eastern hemlocks potentially resistant to the hemlock woolly adelgid. In Proceedings of the Fourth Symposium on Hemlock Woolly Adelgid in the Eastern United States, Hartford, CT, USA, 12-14 February 2008; Onken, B., Reardon, R., Eds.; USDA Forest Service: Morgantown, WV, USA, 2008; pp. 124-134.

17. Butin, E.; Preisser, E.; Elkinton, J. Factors affecting settlement rate of the hemlock woolly adelgid, Adelges tsugae, on eastern hemlock, Tsuga canadensis. Agric. For. Entomol. 2007, 9, 215-219.

18. Jetton, R.M.; Hain, F.P.; Dvorak, W.S.; Frampton, J. Infestation rate of hemlock woolly adelgid (Hemiptera: Adelgidae) among three North American hemlock (Tsuga) species following artificial inoculation. J. Entomol. Sci. 2008, 43, 438-442.

19. Newton, L.; Frampton, J.; Monahan, J.; Goldfarb, B.; Hain, F. Two novel techniques to screen Abies seedlings for resistance to the balsam woolly adelgid, Adelges piceae. J. Insect Sci. 2011, 11, 158.

20. Jetton, R.M.; Mayfield III, A.E.; Powers, Z.L. Development of a rain down technique to artificially infest hemlocks with the hemlock woolly adelgid, Adelges tsugae. J. Insect Sci. 2014, 14, 106.

21. SAS Institute Inc. SAS Version 9.4; SAS Institute Inc.: Cary, NC, USA, 2012.

22. McClure, M.S. Density-dependent feedback and population cycles in Adelges tsugae (Homoptera: Adelgidae) on Tsuga canadensis. Environ. Entomol. 1991, 20, 258-264.

23. Mayfield, A.; Jetton, R. A shady situation: Evaluating the effect of shade on hemlock woolly adelgid densities on potted hemlock seedlings. In Proceedings of the 55th Southern Forest Insect Work Conference, New Orleans, LA, USA, 23-26 July 2013; p. 43. 
24. Oten, K.L.F. Host-Plant Selection by the Hemlock Woolly Adelgid, Adelges Tsugae Annand: Sensory Systems and Feeding Behavior in Relatizon to Physical and Chemical Host-Plant Characteristics. Ph.D. Thesis, North Carolina State University, Raleigh, NC, USA, October 2011.

(C) 2015 by the authors; licensee MDPI, Basel, Switzerland. This article is an open access article distributed under the terms and conditions of the Creative Commons Attribution license (http://creativecommons.org/licenses/by/4.0/). 